\title{
The Dormancy, Rise and Decline of Fundamental Liberties of States
}

\author{
Stephen C Neff*
}

\begin{abstract}
Fundamental liberties of states, if they exist, should be seen essentially as analogues of civil liberties in national legal systems, ie, as 'privileges' in the sense in which Hohfeld employed that term. In the natural-law era, there was no room for any conception of fundamental liberties of states, since natural law was basically a law of duties rather than of rights. Only with Hobbes did the idea arise of a rights-based natural law. In the eighteenth century, Wolff and Vattel advanced the idea of a duty of states to strive towards perfection-but this was a duty rather than a liberty. Only in the positivist era of the nineteenth century, with its strongly state-centred ethos and its stress on the independence of states, did a concept of fundamental liberties of states emerge, with various lists proposed by various authors. Even there, the idea was meaningful only in the context of legislative (as opposed to a contractual) picture of customary international law. Various positivist writers advanced lists of fundamental liberties. Some positivist writers, however, such as Westlake, opposed the idea, as did Kelsen later. Nor is there significant support for the idea in state practice. Repudiations of treaties, most notably, have not entailed an invocation of fundamental liberties. Neither self-defence nor non-intervention qualifies as a liberty. Similarly, neither the principle of freedom (from the Lotus case), nor the persistent objector principle lend support to the concept of fundamental liberties of states.
\end{abstract}

\section{Keywords}

Natural Law, Hohfeld, Liberties, Hobbes, Duty of Perfection, Positivism, Persistent Objector, Selfdefence, Principle of Freedom, Kelsen

An assertion of the existence of a body of fundamental rights of states must immediately give rise to a feeling of great ambivalence. On the one hand, it may smack of idealism, in the way that support for fundamental human rights has done. At the same time, however, suspicions will immediately arise that the idea would operate to extend the prerogatives of states at the expense of individuals-and thereby constitute a seriously reactionary step, away from the great mission of advancing international human rights. This ambivalence suggests that those who seek to assert the existence of fundamental rights of states have a challenging task ahead.

* Reader in Public International Law, University of Edinburgh (UK). 
The present discussion will not treat that question, but instead will explore the extent to which, over the course of history, support can be found for a concept of fundamental rights of states. There will first be a discussion of what is meant, precisely, by the idea of fundamental rights of states-or liberties, as they will be termed, for reasons to be explained. This will be followed by expositions on why the concept lay dormant for so long a period, only to arise in explicit form in the nineteenth century. It will then be pointed out how and why the idea has largely faded away since the First World War.

\section{What fundamental rights are-and are not}

When we speak of fundamental rights of states, we are talking about rights that are, in some fashion, more than mere 'ordinary' rights. It is suggested that fundamental rights must be rights which, somehow or other, are protected from being overridden by 'ordinary' rules of international law. Furthermore, it is reasonable to suppose that we must be talking about rights to autonomous action on the part of states-the right of states to act, in some (or all) circumstances according to their own unilateral will.

Consequently, the right of a creditor state vis-à-vis a debtor state would not fall into this category because there is no question here of the exercise of unilateral will on the part of the creditor state. The relationship arises by mutual consent between the two parties. What we are seeking is, instead, a right that is, so to speak, 'free-floating, ie a right which is not merely the counterpart of some other state's duty. The reason for insistence on this point is that, in situations in which a state's right is simply the 'flip side' of some other state's duty, then the discourse can just as easily be about the duty of the one state as the right of the other-and there is, consequently, no reason to focus on rights rather than duties. That is, one could quite as easily devise a doctrine of fundamental duties of states instead of rights. If there is to be a distinctive doctrine of rights of states, then there is a need for some kind of legal code which confers freedom of action onto states in specified areas-something analogous, that is, to a bill of rights in a domestic constitutional setting.

A useful distinction in this regard was made by the American legal philosopher Wesley Hohfeld early in the twentieth century. ${ }^{1}$ He distinguished between rights in the strict and proper sense, and what he called 'privileges' (although 'liberties' would probably be a more apt term to use and will be employed here). An ordinary right entitles the holder to compel some identified party or parties to do something or to refrain from doing something (or, alternatively, to obtain money damages for a failure in either of these regards). The philosopher JL Mackie employs the expression 'claimright' to emphasise this core feature of eliciting some kind of act from another party. ${ }^{2} \mathrm{~A}$

1 Wesley Hohfeld, Fundamental Legal Conceptions as Applied in Judicial Reasoning and Other Legal Essays (Yale UP 1923) 35-64.

2 JL Mackie, Ethics: Inventing Right and Wrong (Penguin 1977) 173-74. 
right in this strict sense corresponds to a duty on the part of the other party or parties, so that rights and duties are therefore the 'flip sides' or counterparts of one another (Hohfeld called them 'correlatives'). ${ }^{3}$ A classic illustration would be the debtor-creditor arrangement just given, in which the creditor's right to receive payment is backed by the debtor's duty to pay-with the right being legally enforceable. In international law terms, an appropriate illustration would be a treaty relation, such as an agreement for the establishment by one state of a military base on the territory of another state. The right of the one state to establish the base is backed by the duty of the other state to allow it. On this analysis, a 'violation of a right' can equally well be characterised as the failure on the part of the wrongdoer to perform his duty.

The fundamental 'rights' that are of present concern are not, however, of this character. They are what Hohfeld called privileges-and what will here be called liberties. ${ }^{4}$ Liberties differ from rights in several important respects. First of all, liberties are in the nature of shields or barriers, protecting a party from interference by outsiders. Within the scope of a given liberty, the holder is free from any obligations to any other parties. A liberty is (in more modern terminology) a juridical space in which the holder of the liberty can freely exercise his unilateral will. In this respect, liberties might be thought of as the opposite of rights, which (as just noted) are, by definition, the ability to interfere with the normal freedoms of others-for example, to compel another party to supply widgets when the general law imposes no such duty. As Hohfeld crisply put it, 'A right is one's affirmative claim against another, and a [liberty] is one's freedom from the right or claim of another. ${ }^{5}$

More specifically, it may be said that a liberty has two key features. One is that the holder of a liberty is free to exercise it at will. That is to say, he is under no obligation to refrain from exercising it. Obligation and liberty, in other words, are mutually exclusive opposites. The second key feature of a liberty is the absence of a right on the part of anyone else to compel the holder to refrain from exercising his free will. In Hohfeld's terminology, the counterpart of a liberty is a 'no-right' on the part of all other persons in the world. ${ }^{6}$ Examples of liberties would include freedom of expression, religious freedom or freedom of movement. It should be noted that, in the case of liberties, persons in the rest of the world (apart from the holder) are not subject to a duty in the strict sense, because the holder of the liberty cannot compel them to do anything. The right to compel is, as just noted, the hallmark of a right, with liability to compulsion being, correspondingly, the hallmark of a duty. For example, a person may have the liberty of free expression, but no one is under a duty to listen. Instead, everyone lacks a right to prevent the speech from taking place. 
It is possible that a person can hold a right against the world in general—or, strictly speaking, against each and every person in the world individually. The law of torts illustrates this point. Person A has, say, a right not to be assaulted; and every other person in the world has a corresponding duty not to assault A. In international law, a state has a right not to have armed force used against it; and every other state has a corresponding duty not to employ such force. These are illustrations of rights and not liberties, because there is always an identifiable party (or parties) who are under a correlative-and enforceable-obligation not to engage in certain conduct. It must be remembered that the essence of a liberty is not the right to stop other people from doing things (eg, an aggressor from succeeding in its attack), or to compel other parties to perform their duties (eg, a debtor to pay his debt). It is, instead, the ability to act autonomously without anyone else having a right to interfere.

\section{The dormancy: The era of natural law}

The notion of fundamental liberties of states (to keep to the terminology adopted) is of relatively recent vintage. It is a fruit of nineteenth-century positivism. During the Middle Ages, and well beyond, no one had the least idea of the notion, for reasons that will be explained. It was only in the seventeenth century, with the writing of Thomas Hobbes, that a discourse of liberties came into a clear focus for the first time. And even that was largely concerned with liberties of individuals. The potential implications for states were clear to see, but the major eighteenth-century writers still hesitated to draw those clear conclusions, preferring instead to continue thinking along the old lines marked out by natural law thought.

\subsection{The age of natural law}

Medieval writers would have been astonished-not to say appalled - at the very notion of fundamental liberties of states. There were two principal reasons for this. One is that states were regarded as artifacts of human depravity, existing only by virtue of mankind's fall from grace. This fundamentally negative idea of statehood and government as such was a distinctively Christian notion, deriving from the Christian doctrine of original sin. ${ }^{7}$ The leading figure in the development of this doctrine was Augustine of Hippo, at the very outset of the Middle Ages. He regarded states as, essentially, bandit organisations on a large and permanent scale, maintained by brute force rather than by any sense of legitimacy. '[W]hat are kingdoms but great robberies?' he asked rhetorically. ${ }^{8}$ This attitude, it may be noted, was a striking departure from the classical heritage. According

7 Gaines Post, Studies in Medieval Legal Thought: Public Law and the State 1100-1322 (Princeton UP 1964) 496-97, 499-500; Ernst Cassirer, The Myth of the State (Yale UP 1946) 108-11.

8 Augustine of Hippo, 'The City of God' in Whitney J Oates (ed), Basic Writings of Saint Augustine (first published c AD 418, Random House 1948) vol 2, 51. 
to Aristotle, the state is a natural entity, essential for enabling people to lead the fulfilling life which is (to Aristotle) the basic goal of all persons. ${ }^{9}$

The other factor which made acceptance of the idea of fundamental liberties of states impossible was the nature of the dominant mode of legal thought at the time: natural law. For one thing, natural law focused overwhelmingly on duties rather than rights (or liberties). In addition, natural law was not primarily concerned with states at all. Its primary concern was interpersonal relations between individuals. It is true that, in principle at least, the rules of natural law applied equally to rulers as to ordinary people. In that sense, natural law was relevant to the affairs of states. But it was not directed primarily to issues of relations between rulers, or between states as such, in the manner of modern international law.

The difficulty in finding liberties in natural law is well illustrated by the question of self-preservation. Thomas Aquinas readily recognised this as a fundamental principle of natural law. In a sense, self-preservation was a duty, in that the law of Christianity prohibited persons from taking their own lives. Self-preservation could also be seen, at the same time, as a right, because all other persons were under a duty not to take the lives of others.

An argument could be made, though, for self-preservation as a liberty, at least in the marginal, but intriguing, case of a starving person who wishes to pilfer food from the larder of someone who is better off. If this were allowed, then it could well qualify as a liberty, in that it would be a case of a person being unilaterally able to take certain actions at will. It might be objected, however, that the larder owner does have a legal right to stop the self-help measure; and if this were so, then there would not be a liberty. (At most, there would merely be an immunity from prosecution of the poor person.) There is a liberty to take food only if there is, correspondingly, no right on the food owner's part to fend off the starving person. And this is open to considerable debate. Some writers, such as Augustine, dealt with this difficulty by contending that, in such a case of necessity, the food owner's property right vanishes. If that were the case, thenbut only then-there would be a true liberty on the starving person's part, since the erstwhile owner's right to stop the food taking would be extinguished. The pauper would possess not merely a right of self-preservation (coupled with a duty on the part of others not to kill him), but also a liberty to do whatever is necessary under the circumstances to stave off death. If, in contrast, the food owner was held to be under a legal obligation to supply sustenance to his unfortunate fellow creature, then of course the starving person would possess a right rather than a liberty.

\subsection{Hobbes and the birth of 'rights' discourse}

It was only in the seventeenth century that natural law thought crossed the conceptual Rubicon of becoming based on liberties rather than on duties. The seminal figure in 
this important change was Thomas Hobbes. Here too, the basic thinking concerned the liberties not of states, but rather of individuals-and specifically of individuals existing in a state of nature. The Hobbesian state of nature was no paradise-far from it. It was a condition of high insecurity, ever-present danger, and worrisome competitiveness. In Hobbes's famous (perhaps too famous) words, it was a condition in which life was all too likely to be 'solitary, poor, nasty, brutish and short. ${ }^{10}$ In this frightening environment, there was (in Hobbes's view) one basic, fundamental human liberty: self-preservation. This was a liberty in the true sense, because Hobbes insisted that, in the state of nature, no one possesses a right to stop anyone else from doing whatever is necessary for selfpreservation. In the state of nature, Hobbes maintained, 'nothing is unlawful to any man that tendeth to his own safety or commodity. ${ }^{11}$

Speaking in sober jurisprudential terms, the Hobbesian state of nature may be characterised as a situation in which there were overlapping liberties-where, in Hobbes's words, there is 'the right of all to all, wherewith one by right invades, the other by right resists, and whence arise perpetual jealousies and suspicions on all hands. ${ }^{12}$ There were no clearly delimited bounds separating one party's freedom of action from that of another. Consequently, there was an ever-present risk, or even reality, of clashing claims. And in the absence of a neutral adjudicator of some kind, these clashes would constantly risk turning violent. Fortunately, a solution was at hand, though a drastic one. That is, that each person, in coordination with all others, would voluntarily surrender his fundamental liberty of self-preservation to a single sovereign power. That sovereign would then proceed to impose and enforce order, and to lay down rules that would delimit the freedom of action of each subject from that of others. In short, a total surrender of liberty would bring peace and security.

Once this act of surrender-and-subjection had taken place, the state would be born. Hobbes supposed that this process would occur separately and spontaneously in local areas all over the earth, with the result that there would be a number of sovereign states. Each sovereign would be supreme in its own jurisdiction. But, vis-à-vis other states, it would be in a state of nature. '[T] hat which is the law of nature between man and man, before the constitution of commonwealth', asserted Hobbes, 'is the law of nations between sovereign and sovereign, after. ${ }^{3}$ Consequently, the same considerations as before would apply with virtually mechanical exactitude. Self-preservation would continue to be the single supreme liberty. But now-for the first time-it was clearly seen to be a fundamental liberty of states as such, rather than of individuals. States, like individuals before them, are entitled, under the Hobbesian approach, to perform whatever acts are

10 Thomas Hobbes, Leviathan, or The Matter, Form and Power of a Commonwealth Ecclesiastical and Civil (first published 1651, Blackwell 1947) 84.

11 Thomas Hobbes, 'Human Nature' in JCA Gaskin (ed), The Elements of Law, Natural and Politic (first published 1640, OUP 1994) 103.

12 Thomas Hobbes, De Cive, or The Citizen (first published 1647, Appleton-Century-Crofts 1949) 29.

13 Thomas Hobbes, 'De Corpore Politico' (first published 1640) in JCA Gaskin (ed), The Elements of Law, Natural and Politic (first published 1640, OUP 1994) 182. 
necessary under the circumstances to ensure self-preservation or survival. Other states have no legal right to put a stop to those acts. Other states may, of course, have the material power to interfere with these actions. But they have no legal right to do so.

\subsection{Wolff, Vattel and the duty of 'perfection'}

In the generations following Hobbes, a split emerged in natural law thinking. The Hobbesian (or 'naturalist') school, true to the teachings of their master, tended to emphasise the fundamental liberty of self-preservation. Spinoza, for example, held with Hobbes that 'men in the state of nature are enemies. ${ }^{14}$ Also like Hobbes, he concluded that persons in this perilous condition possess the liberty to take whatever steps are necessary to attain security and self-preservation. ${ }^{15}$

The predominant strain of natural law thought, however, continued, in the traditional vein, to emphasise duties of states, rather than rights. This was true even in cases in which the prerogatives of states were actually being asserted. Nowhere was this seemingly paradoxical state of affairs better illustrated than in the writings of the eighteenth-century German natural lawyer Christian Wolff, and then of his Swiss follower and populariser Emmerich de Vattel.

Wolff (and Vattel after him) posited the existence of a duty on the state's part to strive for what he called 'perfection.' ${ }^{16}$ This clearly meant something far more than bare survival, although it did include that. More broadly, though, it meant, in Wolff's rather vague exposition, a duty to do all things necessary to achieve a state's 'fitness for accomplishing the purpose of the state'. For Wolff, a liberty is present here, albeit only as a consequence of the duty: if there is a duty to seek perfection, then there must logically be a liberty to undertake such acts as are necessary to bring that perfection about. As he put it, 'every nation has the right to those things without which it cannot perfect itself, and its form of government. ${ }^{17}$

If this duty to seek perfection is to be seen as a duty in the strict sense of Hohfeld, the question would immediately arise: to whom is this interesting duty owed? Wolff had a ready answer: it was owed by the state to itself. That is to say, the state was the holder of both the right and the duty simultaneously. It is, of course, difficult (to say the least) to see this as a true right in Hohfeld's sense, since the key hallmark of a right-and-duty complex-enforceability-would seem to be lacking. How can a state (or individual for

14 Baruch Spinoza, 'Theological-Political Treatise' in AG Wernham (ed), The Political Works (first published 1677, Clarendon Press 1965) 295.

15 On Spinoza and natural law, see Jon Miller, 'Spinoza and Natural Law' in Jonathan A Jacobs (ed), Reason, Religion, and Natural Law (OUP 2012) 201-21.

16 Christian Wolff, The Law of Nations Treated According to a Scientific Method (first published 1764, Clarendon Press 1934) 20-22, 24-28.

17 ibid 25. On Wolff's ideas about natural law, see Tim Hochstrasser, Natural Law Theories in the Early Enlightenment (CUP 2000) 150-86; Knud Haakonssen, 'German Natural Law' in Mark Goldie and Robert Wokler (eds), The Cambridge History of Eighteenth-Century Political Thought (CUP 2006) 268-78. 
that matter) enforce a duty which it owes to itself? This is an instructive indication of the extent to which the traditional natural law tendency to think in terms of duties rather than of rights still exerted a strong hold on European thinkers in the eighteenth century.

Notwithstanding this small difficulty, Wolff was clear on another point: that the duty of perfection-and, more generally, the corpus of duties that a state owes to itself-takes precedence over the duties that it owes to other states. This idea of states owing their primary duties to themselves, and only their secondary duties to other states would be given a new twist in the nineteenth century. But we can see here the germs of the idea of fundamental liberties of states-even though it was 'disguised', so to speak, as a duty rather than as a right or liberty.

Vattel endorsed these views of Wolff. But he also went on to posit a concrete situation in which a state would have the right to repudiate a treaty without any breach by the other side, essentially as a matter of inherent right. This was the scenario in which a peace treaty was concluded after a war which was not the outcome of true bargaining, but instead was a mere instance of 'oppression' on the part of the triumphant side. 'If an ambitious and unjust conqueror subdues a Nation', Vattel explained, 'and forces it to accept hard, disgraceful, and unendurable terms of peace, necessity may constrain the Nation to submit to them. But this show of peace is not real peace; it is oppression.' The so-called peace arrangement is, in reality, 'a yoke which men of spirit will throw off upon the first favorable opportunity'. The sole specific illustrative instance that he gave was the defeat of the Aztec Empire by Hernando Cortés in the early sixteenth century. Vattel was aware that this liberty of repudiating peace treaties could be subject to abuse; but he nevertheless held that the risk should be taken, since natural law 'does not favor oppressors. $^{18}$

This example of Vattel is open to conflicting interpretations. On the one hand, it might be contended that the victorious state was in violation of a legal duty under customary law to be moderate in its treatment of defeated opponents. In that case, the defeated state would be asserting a legal right that is correlative to that duty. On the other hand, it might be contended that the victorious state was under no such customary law duty and committed no legal wrong in imposing a harsh peace. In that case, the defeated state would be exercising an inherent right of some kind to overthrow or repudiate the harsh arrangement. This would be a liberty in the true sense-provided, of course, that the victorious state had no legal right to stand in the defeated state's way. This example by Vattel is a very instructive illustration of how difficult it is, in practice, actually to find, or even to imagine, a clear instance of an exercise of a fundamental liberty by a state.

18 Emer de Vattel, The Law of Nations, or The Principles of Natural Law Applied to the Conduct and to the Affairs of Nations and of Sovereigns (first published 1758, Carnegie Institution of Washington 1916) $356-57$. 


\section{The rise: Nineteenth-century positivism}

In a number of important respects, the positivist legal philosophy of the nineteenth century was more conducive to the idea of fundamental liberties of states than natural law had been. ${ }^{19}$ One important reason for this was the increased focus of the positivists on states as the exclusive subjects of international law. Strong support was given to this thesis by the positivist insistence on what was sometimes called the 'real personality of the state. ${ }^{20}$ The supreme figure behind this insistence on the real personality of the state was the German writer Otto von Gierke, who was a clear heir to the Hegelian tradition. ${ }^{21}$ There was widespread agreement, especially among German writers, on this point. The German scholar Heinrich Triepel, a noted constitutional as well as international lawyer, for example, was a strong advocate of the real personality of the state. ${ }^{22}$ If ever there was an atmosphere conducive in general to ideas of fundamental liberties of states, it would be here.

Another important attribute of positivism that bolstered the idea of fundamental liberties of states was its principled rejection of the binding authority of natural law. This had the effect of freeing states from their erstwhile servitude to the manifold duties which natural law imposed onto them. It thereby cleared the way for the devising of a system of international law that was based on liberties instead. The result of this new way of thinking was to see international law as being man-made, as being the creation of states. Since states were now seen as the creators of international law, then naturally the creators would be expected to have their own interests firmly in mind during the creation process.

Also lending support to the concept of fundamental liberties of states was ready acceptance by positivists of the notion that international law is not necessarily a comprehensive system, ie that certain areas of inter-state relations can be left unregulated by law. This conclusion arises immediately from the positivist view of law as wholly man-made. It is entirely foreseeable that there might be some areas in which no rules had been agreed upon. ${ }^{23}$ In such a case, something which the World Court later labelled 'the principle of freedom' applied: states are free to do as they wished, if no rule of law existed to constrain their action. ${ }^{24}$ 'Restrictions upon the independence of States', the Court pronounced, 'cannot (...) be presumed.'

19 Stephen C Neff, Justice Among Nations: A History of International Law (Harvard UP 2014) 245-47.

20 George H Sabine and Walter J Shepard, 'Translator's Introduction' in Hugo Krabbe, The Modern Idea of the State (Martinus Nijhoff 1922) xi-lxxxi.

21 On Gierke, see John D Lewis, The Genossenschaft-Theory of Otto von Gierke: A Study in Political Thought (University of Wisconsin 1935); David Runciman, Pluralism and the Personality of the State (CUP 1997) 34-63.

22 Janne E Nijman, The Concept of International Legal Personality: An Inquiry into the History and Theory of International Law (TMC Asser Press 2004) 118-19.

23 See, to this effect, Lassa Oppenheim, 'The Science of International Law: Its Task and Method' (1908) 2 AJIL 313, 335-36.

24 SS Lotus Case (France v Turkey) (Merits) PCIJ Rep Series A No 10.

25 ibid 18. 
It might be wondered if this principle of freedom could be an alternate name for fundamental liberties of states. That might be so, in that, in the areas where no rule of law is in force, states have full freedom of action, with no other state having a right to interfere-the hallmarks of a liberty in the strict sense under consideration. It should be appreciated, though, that such a liberty (or set of liberties) is a far cry from a menu of specified rights or a bill of rights. It is merely a negative or residual category of actions outside the purview of the law altogether. ${ }^{26}$ It comprises simply whatever the law happens not to cover at any given time. Moreover, the content of this residual category is necessarily in constant flux-ie constantly diminishing-as the body of international law gradually becomes more and more comprehensive.

Some of the variants of nineteenth-century positivism allow for fundamental liberties of states in this very pale and attenuated sense. There is, for example, the version of positivism known as voluntarism, which stressed unilateral self-limitation by states as the essence of international law. ${ }^{27}$ The conclusion immediately follows that, in any area in which states have chosen not to accept limitations on their acts, freedom of action remains. There is also the common-will version of positivism, which stressed treaty-making as the source of international legal obligation. ${ }^{28}$ Here too, the conclusion immediately follows that, in any area in which states have not entered into treaty obligations, freedom of action remains.

\subsection{Customary law and fundamental liberties of states}

Somewhat more interesting, for present purposes, is the third variant of positivism, the empirical one. ${ }^{29}$ This one stressed the formation of customary law through state practice at the heart of international legal doctrine. The rules of international law were seen to arise out of the will of the states of the world; but it is important to appreciate that this meant the collective will of the states in general, not the individual, idiosyncratic wills of each state on its own.

Regarding the question of fundamental liberties of states, much depends on which of two rival views of customary law is taken: the legislative or the contractual. According to the legislative view of customary law, customary law rules are rules that are, per se, binding on all states, in the manner of legislation in domestic laws, which binds all persons within a given jurisdiction. If the custom comes about through the unanimous practice of states, then there is no difficulty. But if some states dissent from the practice, then they are overruled once the rule of law is established, just as opponents of legislation become subject to a law even if they objected to its enactment.

26 See, on this point, Neff (n 19) 249.

27 On the voluntarist version of positivism, see ibid 236-43.

28 On the common-will version of positivism, see ibid 231-36.

29 On the empirical version of positivism, see ibid 226-31. 
According to the contractual view of customary law, in contrast, the law binds only those states that actually participate in its making, or which actually give their consent. On this view, customary law is simply tacit treaty-making. Just as a treaty binds only the states that are parties to it, so customary law binds only the states that either participate in the relevant practice or which give their consent to the rule. In the nineteenth century, this contractual outlook was the dominant one. ${ }^{30}$

It will be immediately apparent that, if the contractual view of customary law is adopted, then the question of the fundamental liberties of states scarcely arises. More accurately, it should be said that, on the contractual view, there is really only one fundamental liberty of states: the liberty to decline to participate in the formation of customary rules. This is, of course, a straightforward analogue of the fundamental liberty of states to decline to become parties to treaties of which they disapprove. It is also, for all practical purposes, simply the principle of freedom in action yet again-though now, states are allowed consciously to choose to reside in the unregulated zone. Like the principle of freedom, this liberty is clearly of a wholly negative nature, quite different in character from menus of liberties which appear in constitutional bills of rights in national legal systems. This solidary fundamental liberty is more in the nature of a freedom to be a hermit. It does not amount to a grant of a body of liberties under the rule of law.

\subsection{Doctrinal support for the idea}

An early supporter of the idea of fundamental rights of states was the German writer Johann Ludwig Klüber. Anticipating Hohfeld, he made the potentially important distinction between fundamental and non-fundamental rights of states-or, in his parlance, between the absolute and the conditional rights of states. The absolute rights were conservation (ie self-preservation), independence and equality with other states. The conditional rights were those that arose out of particular contexts-most obviously out of treaties concluded with other states. ${ }^{31}$ Later in the century, in 1885, the French writer Paul Pradier-Fodéré made a similar distinction. He contrasted two categories of states' rights, which he called accidental and inherent. Accidental rights were those which flowed from particular circumstances, such as treaty negotiations. Inherent rights, in contrast, were those which a state possessed as an attribute of statehood as such. ${ }^{32}$

The American author Henry Wheaton, in the 1830s, posited two absolute rights of states: independence and self-preservation. ${ }^{33}$ The German scholar and judge Auguste Heffter, perhaps the earliest writer to take a consciously positivist perspective, was

30 See, eg, Theophile Funck-Brentano and Albert Sorel, Précis du droit des gens (2nd edn, E Plon Nourrit 1887) 3; Dionisio Anzilotti, Cours de Droit International: Introduction-Théories Générales (Gilbert Gidel tr, Sirey 1929) 73-77, 87-90. See also Neff (n 19) 247-49.

31 Albert de La Pradelle, Maîtres et Doctrines du Droit des Gens (2nd edn, Éditions Internationales 1950) 192.

32 Paul Pradier-Fodere, Traité de Droit International Public Européen et Américain: Suivant les Progrès des Sciences et de la Pratique Contemporaines (A Durand et Pedone-Lauriel 1885) 472-73.

33 Henry Wheaton, Elements of International Law (Carey, Lea and Blanchard 1836) 81-82, 95-129. 
especially outspoken on the subject, identifying four fundamental rights of states: free existence and independence; sovereignty; a right to mutual respect from other states; and a right to mutual commerce with other states (including a right to diplomatic relations as well as a right to trade). ${ }^{34}$ The Argentine writer Carlos Calvo, one of the foremost writers in this empiricist tradition, insisted on a basic right of 'conservation' on the part of state, calling it 'the first of all permanent and absolute rights'. It was inherent in the fundamental principles of state sovereignty and independence and thereby constituted, in his view, 'the supreme law of nations. ${ }^{35}$

At the end of the century, the influential French treatise writer Henry Bonfils, writing in 1894, identified three fundamental rights: conservation; interior sovereignty (meaning autonomy); and external sovereignty (meaning independence). External sovereignty was held, in turn, to comprise three components: the right to equality with other states; the right to respect from other states; and the right to freedom of commerce (ie freedom from economic monopoly claims of third powers). ${ }^{36}$ One of the very strongest assertions of the principle of fundamental liberties of states came from the Swiss writer Alphonse Rivier in $1896 .^{37}$

\subsection{Some doubts}

Several important points may be noted about this support for the idea of fundamental liberties of states. One is that it is difficult to see the need for it, given the prevailing view at the time that customary law was contractual in character. So long as states were free to hold back from participating in the formation of customary rules, there would seem to be practically little need (as noted above) for a separate and distinct doctrine of fundamental liberties of states. It is not surprising, therefore, to find that writings on the fundamental liberties of states tended to be somewhat abstract and removed from the concerns of everyday international life.

Nor was support for the idea unanimous even among positivist writers. A notable opponent of the concept was John Westlake, of Cambridge University. Writing early in the twentieth century, he disputed the idea of the real personality of the state, insisting instead that 'states are nothing more than associations of natural persons'. He went on to assert that 'it is a logical error to assume, because states are moral persons and therefore capable of rights equally with natural individuals, that they must have the same rights as natural individuals'. In express criticism of Bonfils and Rivier, Westlake maintained that the nature of the state 'is not fixed enough to make it wise to endow it with inherent rights. $^{38}$

34 August Wilhelm Heffter, Le Droit International Public de l'Europe (EH Schroeder 1857) 56-69.

35 Carlos Calvo, Le Droit International: Théorie et Pratique (3rd edn, Pedone-Lauriel 1880) 309-11.

36 Henry Bonfils, Manuel de Droit International Public (1st edn, Rousseau 1894) 123-26, 131-50.

37 Antoine Rivier, Principes des Droits des Gens (Rousseau 1896) 253-407.

38 John Westlake, International Law (2nd edn, CUP 1910) 306-09. 
Another cause for misgiving lay in the fact that it was no easy matter devising a plausible scenario where the principle of fundamental liberties of states could have an impact on state practice. One possibility is the situation put forward by Vattel: that a breach of a fundamental liberty by way of a treaty provision would entitle the victim state to repudiate the treaty without any need to show a breach by the other side. It should be noted, though, there is virtually no evidence for such a thesis in state practice. (Even the Aztec Empire did not attempt to reassert its personhood in international law following the Spanish conquest.)

It is true that, on a number of occasions, states have sought to relieve themselves of burdensome obligations under peace treaties. But these have not involved assertions of breaches of fundamental liberties. Instead, the claims have been much more tightly tailored. One instructive instance occurred in 1870-71, when Russia purported unilaterally to denounce the provisions of the Treaty of Paris of 1856, providing for demilitarization of the Black Sea. ${ }^{39}$ In doing so, however, it made no attempt to invoke any fundamental liberties of states. Instead it relied on change of circumstances as a justification. The other treaty parties, in the event, agreed to release Russia from its obligation under the Treaty-while at the same time expressly asserting that states do not have a unilateral right to denounce treaties, and that the consent of other parties is necessary. ${ }^{40}$

More instructive was the experience of Germany after the First World War. Among German writers, there were assertions to the effect that the Treaty of Versailles (or at least certain provisions) were invalid because they transgressed certain fundamental principles of international law-specifically the principle of equality of states. Carl Bilfinger, who taught international law at the University of Heidelberg during the Nazi period, was one of the prominent figures in this line of thought. ${ }^{41}$ It is notable, however, that this idea was based chiefly on rationalist natural law approaches, and on certain a priori ideas about the nature of statehood. It was not so much an assertion of freedom of will of states in certain respects, as of an entitlement to equal respect and treatment by other states. ${ }^{42}$ It seems, then, more along the lines of a right than of a liberty.

In any event, this idea of a fundamental principle of equality was more evident in the ruminations of scholars than in the practice of states. In 1935, for example, when

39 General Treaty for the Re-establishment of Peace (adopted 30 March 1856, entered into force 27 April 1856) 114 CTS 409, arts 11-14.

40 For this declaration, see Foreign Office, British and Foreign State Papers (James Ridgeway and Sons 1857) vol 61, 7-11. On this incident, see generally David J Bederman, 'The 1871 London Declaration, Rebus Sic Stantibus and a Primitive View of the Law of Nations' (1988) 82 AJIL 1.

41 See Carl Bilfinger, 'Zum Problem der Staatengleichheit im Völkerrecht' (1934) 4 Zeitschrift für ausländisches öffentliches Recht und Völkerrecht 481, 485. For some frank comments on Bilfinger's work and beliefs, see the review by Ernst J Cohn in (1956) 19 MLR 231.

42 Lawrence Preuss, 'National Socialist Conceptions of International Law' (1935) 29 American Pol Science Rev 594, 603-05. 
Germany repudiated the parts of the Treaty of Versailles dealing with arms control, ${ }^{43}$ it did not invoke a purported fundamental liberty on a state's part to provide for its own defence. Instead, the justification, as in the Russian case in 1870, was change of circumstances. Germany contended that the Allied powers were under a parallel obligation to conclude disarmament agreements and had failed to do so. Since the anticipated general disarmament had not occurred, the German restrictions-which were contingent on it-no longer served their originally envisaged purpose. ${ }^{44}$

The same tendency was apparent the following year, when Germany repudiated the Locarno Treaty of 1925, which had safeguarded the country's western frontier arrangements. ${ }^{45}$ This act led directly to Germany's remilitarization of the Rhineland (contrary to the Versailles Treaty). ${ }^{46}$ In taking these actions, the German government did invoke what it called 'the fundamental right of a nation to secure its frontiers and ensure its possibilities of defence. ${ }^{47}$ The formal legal justification that it put to the international community, however, was a more narrow and traditional one: that France had committed a prior breach of the Locarno Treaty, by concluding a mutual assistance pact with the Soviet Union in $1935 .{ }^{48}$ It was not suggested that those treaties were automatically void by virtue of incompatibility with any purported fundamental liberties of states.

In this connection, it might be noted that, in the Lockerbie dispute of the 1990s, Libya did not invoke a purported fundamental liberty to decide entirely on its own whether to extradite its own nationals to foreign countries. Instead, it relied, more narrowly, on the terms of the Montreal Convention of $1971^{49}$ —ie on its treaty rights vis-à-vis other treaty parties. In this case, it asserted that Britain and the United States were legally obligated to respect the rights which Libya claimed under the Convention. ${ }^{50}$

Perhaps the most obvious candidate for a fundamental liberty of states is selfdefence. But it is actually more properly characterised as a right, in the strict sense, rather than a liberty. It is a right because other states are under a corresponding duty to refrain from aggression. If we are looking for a true liberty, then a more likely possibility

43 Treaty of Peace with Germany (adopted 28 June 1919, entered into force 10 January 1930) 225 CTS 188 (Treaty of Versailles) arts 159-202.

44 GA Kertesz (ed), Documents in the Political History of the European Continent 1815-1939 (OUP 1968) 474-76. On this dispute, see Charles G Fenwick, 'The Denunciation of the Disarmament Clauses of the Treaty of Versailles' (1935) 29 AJIL 675.

45 Treaty of Mutual Guarantee (adopted 16 October 1925, entered into force 14 September 1926) 54 LNTS 289.

46 Treaty of Versailles, arts 42-44.

47 Kertesz (n 44) 486-87.

48 Statement of Ribbentrop to the League of Nations Council (1936) LNOJ 336. On this dispute, see Quincy Wright, 'The Rhineland Occupation and the Enforcement of Treaties' (1936) 30 AJIL 486; Charles G Fenwick, 'The Relation of the Franco-Soviet Pact to the Locarno Treaty' (1936) 30 AJIL 265.

49 Convention for the Suppression of Unlawful Acts against the Safety of Civil Aviation (adopted 23 September 1971, entered into force 26 January 1973) 974 UNTS 177.

50 Questions of Interpretation and Application of the 1971 Montreal Convention arising from the Aerial Incident at Lockerbie (Libyan Arab Jamahiriya v United Kingdom) (Preliminary Objections) [1998] ICJ Rep 9, 23. 
might be the somewhat wider principle of necessity, as set out in the International Law Commission's Articles on State Responsibility. ${ }^{51}$ But even this is doubtful. The reason is that a state acting under this heading is, strictly speaking, under an obligation not to engage in the conduct in question. It is just that the failure to honour that obligation is excused (ie not sanctioned) in necessitous circumstances. In addition, a state whose rights are infringed by acts of necessity probably does have the right to resist. Therefore, neither of the hallmarks of a true liberty is satisfied even in the wider case of necessity.

In this connection, consider the famous Caroline incident, which took place in 1837 and led to memorable diplomatic correspondence afterwards between Britain and the United States. The incident is generally held to be a definitive statement of law of selfdefence under customary law. ${ }^{52}$ But it is more properly considered as an illustration of the principle of necessity. Britain was not, in that incident, repelling an attack launched against it by the United States. Rather, it engaged in what would now be called a crossborder commando raid against non-state actors who were threatening British rule in Canada. The operation was therefore closely akin to the American operation that killed al-Qaeda chief Osama bin Laden in Pakistan in 2011.

There was no doubt, in either of these cases, of the right of the relevant countries (the United States and Pakistan) to territorial integrity. The critical question-in the parlance of article 25 of the International Law Commission Articles on State Responsibility-was whether the cross-border attacks were 'the only way for the [acting] State to safeguard an essential interest against a grave and imminent peril'. If so, then that fact can constitute a defence to a claim for violation of territorial sovereignty. The important point for present purposes is that a defence to a claim is not the same thing as a liberty. A liberty, as explained above, is an entitlement to act at will. There is no suggestion that engaging in military operations on the territories of foreign countries is something that states are entitled to do at will. The highly demanding criteria for the principle of necessity must first be satisfied.

It might be thought that the distinction just made between a fundamental liberty of states and the principle of necessity is overly fine. One of the fundamental liberties of states, it may be asserted, is precisely a right to take steps 'to safeguard an essential interest against a grave and imminent peril'-steps to be taken at the will of the acting party, provided that the threshold criteria are met. Recall, however, that essential to a liberty is the absence of any right on the part of the impacted state to stop the action. It cannot be contended that, in the Caroline or the bin Laden raid cases, the territorial states had no right to halt the incursions. On the contrary, the United States and Pakistan

51 International Law Commission, Articles on Responsibility of States for Internationally Wrongful Acts, UNGA Res 56/83 (28 January 2002) UN Doc A/RES/56/83, Annex (Articles on State Responsibility) arts 26-30. On necessity in the law of state responsibility, see James Crawford, State Responsibility: The General Part (CUP 2013) 305-15; Roman Boed, 'State of Necessity as a Justification for Internationally Wrongful Conduct' (2000) 3 Yale Human Rights \& Development LJ 1.

52 Foreign Office, British and Foreign State Papers (James Ridgeway and Sons 1857) vol 29, 1129, 1137-38. 
would both have been entirely within their rights to have prevented the incursions from taking place, had they been able to do so.

Another possible candidate for a fundamental liberty of states might be the principle of non-intervention. But here too, there are problems. For one thing, the principle of non-intervention is a right, not a liberty. It is a right in the proper sense, because all states are subject to a duty not to intervene in the affairs of other states. To identify true fundamental liberties of states, it would be necessary to look behind the 'shield' of nonintervention, to find out just what it is that states are allowed to do without interference by other states-ie to find out what it is that other states have no right to stop a given country from doing. It is conceded that a list of these things would be a list of liberties of states in the true sense of the word. But it should be borne in mind that things that lurk behind the non-intervention shield are, in substantial part at least, matters that are within the domestic jurisdiction of states. In the words of the World Court, the principle of non-intervention concerns 'matters in which each State is permitted, by the principle of State sovereignty, to decide freely. ${ }^{53}$ If fundamental liberties of states means nothing more than the sovereign rights of states over their own jurisdictions, then the idea would seem to add nothing of substance to existing international law.

\section{The decline: The twentieth and twenty-first centuries}

If, as just observed, there has been no significant support in state practice for a principle of fundamental liberties of states, there has also been a decline in doctrinal support for the idea since the nineteenth century. Several reasons may be adduced to explain this. One is that there was, in the 1930s (also as noted above) a certain uncomfortable association of the idea with Nazi writings. In addition, much greater attention has been focused, since 1945, on fundamental liberties of individuals, in the form of the development of international human rights law. Concerns for human rights, at least of the civil and political character, would seem to militate in spirit, if not strictly in letter, against the notion of fundamental liberties of states.

Yet another reason for the decline in interest in the idea of fundamental liberties of states is the advent of a different doctrine that is, at least in large part, an effective substitute for it: the doctrine of persistent objection to the formation of customary law. It has been observed above that the idea of fundamental liberties of states only makes sense in the larger context of a legislative, as opposed to a contractual, view of customary law. And in the nineteenth century, it was the contractual position, rather than the legislative one, that held predominant sway among legal writers. Consequently, there was no great role for a doctrine of fundamental liberties to play.

53 Military and Paramilitary Activities in and against Nicaragua (Nicaragua v United States of America) (Merits) [1986] ICJ Rep 14, 107-08. 
An important change took place in the twentieth century, with the growth of a challenge to the contractual view of customary law. The foremost champions of this change were the members of the Vienna School of the 1920s, whose most prominent figure was Hans Kelsen. Kelsen explicitly rejected the contractual theory of customary law, holding that custom differed from classical legislation in only being a decentralised process. ${ }^{54}$ In addition, Kelsen directly opposed the very idea of fundamental rights-or even duties-of states, on the ground that the norms of international law, in his opinion, spoke not directly to states as such, but rather to the individuals who operated the governmental machinery of states. In other words, like Westlake before him, he rejected the idea of the real personality of the state, which was at the foundation of the idea of fundamental liberties of states. ${ }^{55}$

Whether under the influence of the Vienna School or not, support gradually accrued for what was sometimes called a 'majoritarian' view of international law, ie for what is here called a legislative picture of customary law. ${ }^{56}$ That inevitably gave rise to the predictable fears by some states that rules of law could be foisted on them to which they greatly objected. The way would now seem open for a strong assertion of a doctrine of fundamental liberties of states, when-for the first time in history-it seemed urgently called for as a practical matter. Given the extensive experience of states with domestic protections of civil liberties, it might seem natural that a call might go forth for a doctrine of basic, inalienable liberties to emerge on the international law plane, to counter fears of global mob rule.

This did not happen. Instead, two different strategies have been devised to deal with the problem of the tyranny of majority rule. One is simply to deny the validity of majority rule, per se, in the making of customary law and to insist instead on the classical contractual position. ${ }^{57}$ More common, however, has been the other strategy: supporting the principle of persistent objection to the formation of rules of customary law. There is much that can be (and has been) said about the persistent objector thesis. ${ }^{58}$ Here, it is only necessary to note that this approach does not produce a fixed list of fundamental rights, in the manner of Calvo and the other positivists. Instead, it empowers each individual state, as a matter of unilateral free choice, to pick and choose which rules

54 Hans Kelsen, Principles of International Law (2nd edn, Holt, Rinehart and Winston 1966) 440-41, 453-54. See also Hans Kelsen, General Theory of Law and State (Harvard UP 1946) 351-54.

55 Kelsen, General Theory of Law and State (n 54) 341-43.

56 Ian Brownlie, Principles of Public International Law (7th edn, OUP 2008) 11. On an analogous tendency in treaty law, see Reservations to the Genocide Convention (Advisory Opinion) [1951] ICJ Rep 15, 22.

57 See, eg, Prosper Weil, 'Towards Relative Normativity in International Law?' (1983) 77 AJIL 413, 416-20; Gaetano Arangio-Ruiz, 'The Concept of International Law and the Theory of International Organization' (1972) 137 Recueil des Cours 629, 721-23.

58 Favourable to the principle are Ted L Stein, 'The Approach of the Different Drummer: The Principle of the Persistent Objector in International Law' (1985) 26 Harvard Intl LJ 457; Maurice H Mendelson, 'The Formation of Customary International Law' (1998) 272 Recueil des Cours 155, 227-44. Skeptical of it are Anthony D'Amato, The Concept of Custom in International Law (Cornell UP 1971) 233; Jonathan I Charney, 'The Persistent Objector Rule and the Development of Customary International Law' (1985) 56 BYBIL 1. 
of international law will apply to it-and, more importantly, which will not. It does not produce anything like a true doctrine of fundamental liberties of states, but instead is a doctrine of self-dispensation from individual laws, selected at the respective wills of the various individual objecting states.

The difference between the persistent objector principle and a doctrine of fundamental liberties of states has not been the subject of much (or any) exploration. One important difference is that, under the fundamental liberties approach, there does not need to be any active objection by any state to the rule. The supposed customary rule will be automatically inapplicable simply by virtue of its incompatibility with a relevant fundamental liberty. States might be able to waive their liberties if they so choose. But states electing to stand on their fundamental liberties would not need to take any special action. The persistent objector principle, in contrast, requires some affirmative exertion on the part of the objecting state. But it has the crucial advantage of enabling the objecting states to object to any customary rule, entirely at its own choice-provided, of course, that the objection is sufficiently timely and emphatic. A doctrine of fundamental liberties of states, in contrast, is (presumably) a fixed list of liberties, which states are not free to expand at their own unilateral election.

Speaking more broadly, it may be said that the persistent objector principle and a doctrine of fundamental liberties of states, even if both function as weapons against majoritarian tyranny, are radically different in spirit from one another. The idea of fundamental liberties has an aura of idealism and grandeur to it. It connotes an overriding sense of justice. The persistent objector principle, in sharp contrast, has little (or nothing) of the clarion call about it. Compared to a doctrine of fundamental liberties of states, it is a rather simpering, furtive thing. It is a sort of ad hoc, do-it-yourself means by which states can preserve what they regard as fundamental rights. It is, in the words of one commentator, a device for achieving ' $\mathrm{t}$ ] he reduction of custom to a question of special relations' between states, ${ }^{59}$ ie for reverting, in effect if not (quite) in name, to the contractual view of customary law.

There is a rich irony here. An acceptance of the validity of the persistent objector principle has given rise, in its turn, to some worries of abuse. If states have an absolutely free hand to stop any nascent rule of customary law from applying to them, then states could possibly escape the reach of some highly important rules of law. This fear has given rise, not surprisingly, to a search for rules of law that are outside its reach-ie for rules of law that cannot be disclaimed by states under any circumstances whatever. This becomes, in effect, a doctrine of fundamental duties of states-the very opposite of fundamental liberties. These fundamental duties are, of course, the peremptory norms of international law, of which both the Vienna Convention on

59 James Crawford, Brownlie's Principles of Public International Law (8th edn, OUP 2012) 28. 
the Law of Treaties (1969) and the International Law Commission's Articles on State Responsibility (2001) speak. ${ }^{60}$

\section{Final remarks}

The ups and downs of the concept of fundamental liberties of states provide a useful index to the nature of international law, as it has been perceived at different times in history. In particular, it sharply illustrates the distinction between the natural law period, with its focus on the duties of individuals, and the positivist era of the nineteenth century, with its stress on the prerogatives of states.

It is suggested that the concept of fundamental liberties of states is, in reality, simply an alternate-and confusing-label for what are better described as the set of things which fall into the domestic jurisdiction of states, and which consequently are protected by the 'shield' of the principle of non-intervention. But this is an unnecessarily confusing way of putting the matter. For one thing, rights which fall within the domestic jurisdiction of states are not necessarily fundamental. Some are, in fact, quite trivial (such as rules about procedures to be followed in property transfers). More importantly, the set of things which fall into the category of domestic jurisdiction of states (ie within the purview of state sovereignty) is far from immutable. On the contrary, it is in constant flux, subject to the changing conditions of international life. For example, the fixing of rules about the conduct of criminal trials or the punishment of speech critical of governments were once considered to fall within the domestic jurisdiction of states. But, with the advance of international human rights law, that is no longer so.

Consequently, it would appear that no prerogatives of states can be considered fundamental, in the sense that they are fixed or inalienable or inherent in the concept of statehood as such. The domestic jurisdiction of states (ie the juridical space accorded to state sovereignty) is not a fixed, unalterable menu of fundamental liberties. Rather, it is a residuary category, comprising areas of action that happen not to be regulated by international legal norms at any particular, given time. As such, the category is constantly subject to attrition in accordance with the collective needs of the international community over the course of history. It may be contended that there are certain areas which are not subject to this attrition. But no significant evidence supports that view. For better or worse, there is no theoretical or principled limit to the reach of international law, comparable to the privileged categories of liberties that exist in national constitutions. The age of doctrinaire positivism has passed.

60 See Vienna Convention on the Law of Treaties (adopted 23 May 1969, entered into force 27 January 1980) 1155 CTS 331, art 53; International Law Commission, Articles on State Responsibility, arts 40-41. 